\title{
As liñas en galego do Theatro Moral y Político de la Noble Academia Compostelana (1731) de Pablo Mendoza de los Ríos*
}

\author{
Ramón Mariño Paz \\ Universidade de Santiago de Compostela
}

\section{O texto no seu contexto}

Durante o século XVIII as academias, públicas ou particulares, configuráronse como asociacións non alternativas, senón máis ben complementarias da aula universitaria ou do apartado gabinete en que o erudito, o filósofo ou o científico consumían as horas entregados ó estudio. Nas academias había lugar tanto para a grave discusión sobre temas filosóficos, científicos, morais, etc. coma para o divertimento desenfadado procurado a través das composicións satírico-burlescas escritas en prosa ou verso. Gracias a elas comezaba a resultar un pouco máis fácil a circulación e o intercambio de libros, a circulación e o intercambio de ideas. $\mathrm{O}$ avivecemento do comercio intelectual observable ó longo de toda a centuria foi creando uns circuítos culturais en boa parte emanados da universidade pero en parte tamén independentes dela: tralas academias virían as Sociedades Económicas de Amigos do País, os Ateneos Científicos, as revistas literarias e a prensa en xeral, nunha dinámica que sen solución de continuidade conduciu ata o século XIX. Toda esta actividade, ó cabo, acabou conferíndolle nova vida a unha universidade galega e española que chegara ó século XVIII anquilosada na perpetuación de vellos esquemas e ideas chamados a desaparecer irremisiblemente co triunfo das luces da razón e a ciencia positiva.

O 28 de xaneiro de 1731, nunha casa da rúa compostelá da Moeda Vella, fundaba a Academia Compostelana un grupo de oito estudiantes universitarios de leis dos chamados manteístas, é dicir, dos que non tiñan bolsa nin no Colexio de Fonseca nin no de San Clemente de Pasantes. Ó acto asistiron varios notables da cidade de Santiago entre os que se encontraban Juan de Mantiñán y Orgeiras, rector da Universidade, e José Benito Cadaval Zela y Montenegro, rector do Colexio de Fonseca. A Academia estaría presidida por Pablo Mendoza de los Ríos e as súas sesións, seguramente, desenvolveríanse conforme as pautas xerais que antes sinalei de maneira sumaria, con tempo para o debate serio e circunspecto sobre temas considerados de grande transcendencia, pero tamén para a composición poética de

\footnotetext{
Este traballo realizouse no marco do proxecto de investigación denominado Gramática histórica da lingua galega, posto en marcha polo Instituto da Lingua Galega coa subvención económica da Dirección Xeral de Política Lingüística da Consellería de Educación e Ordenación Universitaria da Xunta de Galicia.
} 
ton menor, para a broma, para a sátira, para o enxeño e a intelixencia epigramáticas. Estou certo de que esta Academia Compostelana non se distinguiu por ningunha circunstancia que no seu tempo a fixese brillar excepcionalmente e lle garantise permanecer na memoria da xente ata hoxe; como moi expresivamente observou Neira de Mosquera (1850: 191) hai un século e medio, nin o máis mínimo recordo quedaría dela "a no ser por un pequeño libro impreso a costa de doscientos ducados, cuyas hojas encontramos cubiertas de polvo en el fondo de un estante apolillado". Esa obra, evidentemente, non é outra có Theatro Moral y Político de la Noble Academia Compostelana (1731), unha especie de libro de actas das sesións celebradas pola academia con algunha cousa máis que escribiu e publicou o seu presidente, o xa mencionado Pablo Mendoza de los Ríos.

Son escasos os datos biográficos que sobre este personaxe achega Antonio Couceiro Freijomil no seu Diccionario bio-bibliográfico de escritores. Baseado na información que ofrecera Antonio Rey Soto na obra Escritores gallegos desconocidos -que eu non dei localizado nin, por tanto, consultado-, Couceiro Freijomil (1951-1954: II, 408-409) limítase a indicar que o noso autor, natural de Burgos, foi relixioso do hábito de San Xoán, que obtivo a encomenda de Quiroga, de onde pasou a prior de Santa María de Castrelo (Ourense)', e que foi "fundador y presidente de la Academia Compostelana, en la que congregó a los más significados hijos de la cultura". Amais do Theatro Moral y Político de la Noble Academia Compostelana, publicou o Epítome de la portentosa vida y milagros de la gran virgen y protomártir Santa Tecla y descripción de las magníficas suntuosas fiestas a la colocación de esta imagen en su nueva maravillosa capilla inclusa en la Santa Metropolitana Iglesia de Burgos, construida a expensas del Ilmo. Sr. D. Manuel de Samaniego y Jaca, su dignísimo arzobispo, del Consejo de $S$. $M$. (Burgos, 1737). Couceiro Freijomil engade que "se cita de él, además, $E l$ peregrino en Santiago, descripción en prosa y verso de las cosas más notables de la ciudad del Apóstol". Ó meu parecer, esta información delata claramente que don Antonio Couceiro non chegou a ter nas mans ou non examinou cun certo vagar o Theatro Moral y Político de la Noble Academia Compostelana, xa que esa presunta obra de Mendoza titulada El peregrino en Santiago non é senón o Tratado Segundo do libro publicado en 1731. Corrobora esta impresión miña que Couceiro diga tamén que ó final do Theatro "se inserta una breve carta satírica en gallego", pois non hai tal: ó que ó final desta obra aparece é unha breve carta en castelán recibida polo fundador da Academia seguida duns versos tamén en

\footnotetext{
Estes tres extremos confírmanse coa lectura da Aprobación do Epítome de la portentosa vida y milagros de la gran virgen y protomártir Santa Tecla que asinou o Padre Pedro Henrique Candeda en Burgos o día 15 de xullo de 1737: "Frey Don Pablo Mendoza de los Ríos [es religioso] del Abito de San Juan, y Prior de Santa María de Castrelo en la Encomienda de Quiroga” (in Mendoza de los Ríos 1737). A información reitérase na "Licencia del Ordinario" da páxina seguinte, dada o día 19 de xullo de 1737 .
} 
castelán e dun diálogo de tons satíricos en que unha das persoas que interveñen utiliza o idioma galego e a outra o castelán².

A obra de 1731 ten o carácter misceláneo que no seu mesmo título se anuncia (Con la adicion curiosa de diversos assumptos, conforme a lo que en ella se practica), o mesmo carácter misceláneo que con toda seguranza terían tamén as sesións da Academia. Ademais de eloxios, prólogos e outros preliminares, contén tres tratados en que se fala sobre o que é a Academia Compostelana e o que moveu o autor a fundala, pero tamén se inclúen discursos morais, unha descrición dos monumentos e a cidade de Santiago (El peregrino en Santiago), outras prosas e poesías dedicadas a diversos asuntos e, para finalizar, un diálogo entre Mendoza de los Ríos e un compañeiro seu en que este se expresa en lingua galega mentres que o burgalés o fai en castelán. A obra, sen dúbida, peca de falta de unidade e creo que carece da máis elemental cohesión interna; mais isto, evidentemente, non lles resta ningún valor ós datos que a propósito da situación da lingua galega no primeiro tercio do século XVIII podemos tirar dela.

Pretendo facer unha transcrición absolutamente fiel das liñas que son obxecto de estudio do meu artigo. Dada a súa extrema brevidade, e dado tamén que non presenta ningún interese para persoas que non sexan especialistas ou polo menos medianamente versadas en historia da lingua galega, non retoco nin sequera a separación de palabras, a puntuación, a acentuación e o uso de maiúsculas. E actúo así porque, por razóns obvias, non destino a edición destas liñas a lectores que se acheguen a elas polo simple e puro pracer de as ler, senón a aqueles que queiran tirar delas algún coñecemento sobre algún aspecto da historia da lingua galega no século XVIII ou nos chamados "séculos escuros" en xeral.

As liñas en galego deste fragmento do Theatro Moral y Político de la Noble Academia Compostelana de Pablo Mendoza de los Ríos foron publicadas por Antonio de la Iglesia nas páxinas $217-218$ do primeiro volume de El idioma gallego (1886), o libro con que, como se sabe, pretendeu demostra-la antigüidade e esencial estabilidade da lingua galega ó longo da historia. Mais, antes ca el, Antonio Neira de Mosquera (1850) xa copiara na páxina 192 de "La Academia Compostelana (1731)" a práctica totalidade da última das intervencións do fidalgo galegófono. Indicarei en nota as variantes de lectura da edición de Antonio de la Iglesia (AI) e mailas de Antonio Neira de Mosquera (ANM), pero non anotarei as discordancias que teñan que ver coa acentuación, a separación de palabras, a puntuación ou o uso de maiúsculas. Posto que, como dixen antes, reproducín con todo rigor a literalidade do texto orixinal, paréceme que realiza-la colación destas miudezas sería facer un esforzo inútil e, o que é peor, mortifica-lo lector deste artigo cunha sobrecarga de información banal. Este é, pois, o diálogo galegocastelán que mantiveron Pablo Mendoza de los Ríos e mailo seu compañeiro:

\footnotetext{
2 Quen si fixo unha correcta descrición do contido do libro foi Atanasio López (1953: 171-172).
} 
[P. 118] Despertè à este tiempo; y cavilando de nuevo entre el penoso Caos de mis dudas, valime de mi Compañero, (que es Letor de Casos desde que estudia en Larraga) y instandole à que me diesse solucion para el Argumento de la Carta, me dixo assi. Vuste meu Amigo soñou vna $^{3}$ cousa dormido, què eu non lla discurrira desperto: respondeulle à Carta, è mais ben; è afellas, que si eu fora como Vustede, mandarallo emprentar; y en canto à essa Encademia, ou

6 como se chama, digalle (pois està mais aquestado en essas cousas, ) que primeyro è saber falar Español, que deprendelle Frances, y en canto à montar Cabalos, bastalles à moytos da Academia vn Putriño para chegar à sua Aldea. No le preguntaba à Vmd. tanto (prosiguì Yò) Reportese otra

9 vez en el modo de hablar de mis Academicos, que sobre ser de las mas calificadas Familias del Reyno, su habilidad es notoria. E Vuste que quere? (dixo el Compañero) ò dito dito, eu non lles quito à sua fidalguia, mays tampouco deyjo ${ }^{4}$ de coñocer, que lles basta para chegar à ${ }^{5}$ suas Casas saberlle montar $v^{6}{ }^{6}$ Putriño; à mais, eu coñeso home que non supo ${ }^{7}$ mays que Larraga è montar Putriñas, è oxe è Cura da miña Filigrisia. Vmd. se desengañe (prosigù Yo) que la ignorancia de honrosos Exercicios es deuda en los Nobles, y desgracia en los Plebeyos, ẽ estos, quando desocupados, y Pobres, y en aquellos, quando Ricos, y ociosos., Xà me fago cargo (me replicò el Compañero) pero os seus Academicos, [p. 119] como lle aprenden para ${ }^{8}$ Letrados, ninguna cousa podian desear mais, que falar ben, è praticar curtesia, que es ${ }^{9}$ ò que Vustedes esprican; E assi oxe por oxe està ben feyto ${ }^{10}$, ò que Vuste fay na sua Academia, pero creiame à min, è deijese ${ }^{11}$ de ela; que à Vuste ninguen lle dà nada; saque ò seu Libriño à mais seus Cartiños ${ }^{12}$, è si pode fagase Crego, è que falen, ninque non falen, calar, que con esso ${ }^{13}$ tèn respondido à moytos tontos; porque sempre verà Vuste, que os Cañòs maldito canto entenden mais, que de facer mofa de todo.

Fálase neste texto dunha carta e dun soño sobre os que convén achega-la información necesaria para quen estea a ler este artigo. Ó parecer, Pablo Mendoza de los Ríos recibiu unha carta en que o remitente desvalorizaba totalmente a Academia Compostelana fundándose, entre outras cousas, non gran defecto de que nela non se ensinaba o idioma francés nin tampouco a montar a cabalo:

Assi dormia la comvn malicia de la ociossidad, y quando acordado menos de la ordinaria, quanto precisa emulacion del Mundo, ò quando pagado mas de mi trabajo, cayò sobre mi esta Carta:

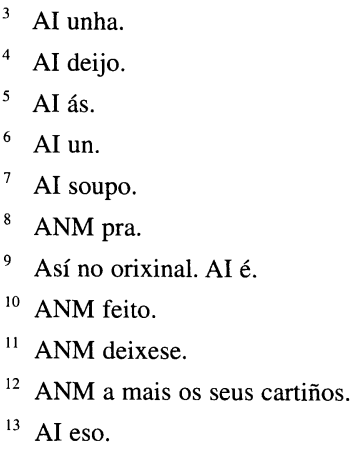


En buena reputacion, Señor Don Pablo, vive el Credito de Vmd. en esta Ciudad, pues hasta los mas Perìtos imaginan, que lo que ay escrito en su Theatro Moral, y Politico importarà tres Pepinos, y que aun esso serà hurtado de Mendoza; que solo la Academia es sacada de su Cabeza, y que esta importa las Coplas de Anton; porque en buen Romanze, no se enseña Frances, ni andar à Caballo (falta que no es de poca monta) y assi, todo lo que se pica es en quatro Textos de Juris, dos Puntos de Cortesia, ciertos Poemas, y buenas Palabras; pero no se aprenden muchas habilidades, que la Academia ignora, y Vmd. no sabe. Dios guarde à Vmd. muchos años.

\section{Hasta aqui la Carta}

Dichoso Pablo (no bien la leì) me decia à mi mismo: no puedo negar mi ventura, pues hasta la Congregacion de los Cismaticos me sepulta en vida, por si acaso me muero de limosna. Jamàs cenè con tan lindas ganas, como aquella noche, y assì apoderãdose de mis Sentidos vna pesadilla (yò creo que era sueño) iba arrullando mi cuydado el que se me dà à mi! y el poco importa: pero juràra, que avia soñado estas Vozes (Mendoza de los Rios 1731: 116).

Seguen despois disto uns versos que conteñen o soño de Mendoza e logo deles aparece xa o diálogo galego-castelán co seu compañeiro. A proposta que nel facía o fidalgo galegofalante viña a ser, en definitiva, a do primum vivere, deinde philosophari, a do pragmatismo dun Sancho Panza á galega contraposto ás quimeras en que se afanaba o quixotesco presidente dunha Academia Compostelana que el estimaba un simple pasatempo para xente ociosa. A interpretación que desta sentencia fixo Neira de Mosquera (1850: 192) paréceme xusta, elocuente, moi atinada:

Estas palabras burlescas equivalían a las líneas severas de un epitafio. La tumba era una ciudad: sepulcro demasiado pequeño para la inteligencia o el ingenio.

No desencanto terminaron, efectivamente, os afáns de Mendoza de los Ríos e os outros académicos. O parágrafo con que o libro remata expresa meridianamente este desengano:

Tan grande Golpe diò en mi acuerdo el sencillo, aunque seguro dictamen de mi Compañero, que desvaneciendo del mio quanto hacia oposicion con su hidea, llamè los Sentidos à juicio, puse en su empleo las Potencias, y despidiendome de mis Academicos con el amor, y cortesia, que aprendi entre ellos, consagrè los postreros acentos deste Libro à la Piedad de quien pendio su aliento (Mendoza de los Rios 1731: 119).

Todo, pois, nos suxire supoñerlle vida efémera á Academia Compostelana fundada en 1731 nunha casa da Rúa da Moeda Vella. 


\section{Estudio linguiístico}

Desque en 1726 publicou un "Discurso Proemial de la Orthographia de la Lengua Castellana" entre os preliminares do seu Diccionario de Autoridades, a Real Academia Española foi puíndo as súas propostas ortográficas a través de sucesivos tratados en que pouco e pouco foi soltando lastre etimoloxicista e camiñando cara á simplificación e ó maior achegamento posible á pronuncia, mais sen romper abruptamente cos usos establecidos durante a xa longa marcha histórica da escritura en castelán. A Academia, preocupada pola prostración en que se encontraba o estudio da ortografía e polo pouco interese por reformala que advertía, investiu grandes esforzos neste empeño, pero tardou moito tempo en conseguir froitos, xa que as inercias con que tiña que loitar semellaban irremontables e os medios de que dispoñía para poder reconducilas resultaban totalmente insuficientes. Os escritores en galego, presos tamén desas inercias como persoas que foran educadas nelas e que maioritariamente escribían en castelán, transpasaron adoito para a súa segunda lingua escrita as normas e usos a que se atiñan para a primeira. Só o Padre Sarmiento, como coñecedor da grafía galega medieval e como dono doutros saberes históricos igualmente importantes, foi quen de idear propostas ortográficas autónomas para o idioma galego do século XVIII. Moi distinto, con certeza, foi o caso de Pablo Mendoza de los Ríos.

En 1726 a RAE incluía as letras $<\mathrm{j}>,<\mathrm{g}>\mathrm{e} \quad<\mathrm{x}>$ entre as que chamaba "unísonas, ò que se equivocan en la pronunciación": $<j>$ e $<x>$ soaban $/ x /$ situadas ante calquera das cinco vocais, como tamén o facía $<\mathrm{g}>$ ante vocal palatal. O uso de $<\mathrm{g}>$ regulábase con criterio etimolóxico, e para o emprego das outras dúas grafías habería que atender tamén "à las raíces de las palabras": $<x>$, que en bastantes casos podía soar $/ \mathrm{ks} /$ (examen, exequias, etc.), usaríase cando os étimos presentaban $<\mathrm{x}>$ (vexación, execución, enxundia, etc.), e "quando las voces tienen en su orígen s: como Caxa, Dexar, Xabón, Xugo, Xeme, que salen de Capsa, Deserere, Sapo, Succus, Semipes: y la razón es, porque la $s$ tiene el sonído muy parecido al de la $x$ : y como los Españóles tomamos de los Arabes la pronunciación guturál, y estos pronúncian las $s s$ como $x$, es natural la conversión de la $s$ en $x, y$ no en $j$ " (RAE 1726-1739: I, p. LXXIV); nos restantes casos escribiríase <j>. As voces castelás dixo $(1.3,10)$ e Exercicios $(1.14)$ poderían facer pensar que o autor das liñas que estamos a comentar se ativo ó que a Real Academia Española prescribira cinco anos antes da publicación do Theatro Moral, pero pouco traballo custaría rexistra-lo conxunto da obra para encontrar exemplos en contrario. Verbo do galego, obsérvase que non hai adecuación ó prescrito para o castelán nin nos casos de deyjo (1. 11) e deijese (1. 18; ANM deixese), que deberían escribirse con $<\mathrm{x}>$, nin nos de oxe (ls. 13,18 ) e $x a ̀$ (1. 15), que esixirían $<\mathrm{j}>$, a letra reservada para "qualesquiera raíces" distintas das sinaladas para $<\mathrm{g}>\mathrm{e}<\mathrm{x}>$. Desde logo, a socialización das normas ortográficas da RAE ía precisar de bastante máis de cinco 
anos para acadar un nivel de cumprimento satisfactorio, de modo que en 1731 aínda era normal a convivencia de dexar e dejar e, por tanto, tampouco resultaría insólito o galego deyjar. Para os que non coñecesen outras linguas románicas, os derivados galegos de HODIE e JAM tiñan que suscitar algunhas dúbidas, xa que os seus cognados casteláns (hoy, ya) non ofrecían solución a primeira vista.

Ante o que ela denominaba "uso promiscuo" que desde había moito tempo se viña facendo de $<$ ç $>$ e $<\mathrm{Z}>$, a RAE decidiu en 1726 prescindir definitivamente de $<$ ç $>$ pero mantendo a duplicidade de $<\mathrm{z}>\mathrm{e}<\mathrm{c}>$ ( $<\mathrm{za}$, ce, ci, zo, $\mathrm{zu}>$, con $<\mathrm{z}>$ en posición final). Adivínase o acatamento desta norma (ou polo menos un uso acorde con ela) a través de Frances (1. 7), coñocer (1. 11) e facer (1. 21), pero alzábase contra ela coñeso (1. 12), que contén un grafema $<s(+o)>$ que garantía unha lectura seseante que tal vez resultaría improbable ou pouco probable en caso de que o autor optase por escribir coñezo. Cómpre advertir de que neste mesmo Theatro Moral, nun "Romance heroico" que forma parte dos preliminares como "Elogio al Presidente de vna señora seglar del Real Convento de Santa Clara de esta ciudad", aparecen en castelán capasidad, susintos, lus, meresido, consepto, safiro, desir e, sen embargo, feliz. Estes usos de $<$ s $>$ por $<\mathrm{z}>$ ou $<\mathrm{c}>$ non se ven no resto do libro, polo que cabe a posibilidade de que Mendoza de los Ríos intentase con eles caracteriza-la fala da anónima señora compostelá de Santa Clara. Mostras de seseo galego equiparables, mutatis mutandis, a estas sinalounas Clarinda Maia (1988) xa en documentos do século XIII, e non faltan tampouco en textos do XVII e o XVIII (cf. Mariño Paz 1995: 41).

Respecto do uso do ese duplo ( $<\mathrm{ss}>$ ) hai que lembrar que a Real Academia Española non o aboliu ata 1763, polo que se atiñan ás normas propostas en 1726 diesse (1. 3) e assi (1. 3), e, dada a facilidade con que a acomodación se podía facer, tamén as voces galegas essa (1. 5), essas (1. 6), assi (1. 18) e esso (1. 20; AI eso).

En troques, non sucedía o mesmo no tocante á especialización dos signos gráficos $<\mathrm{u}>\mathrm{e}<\mathrm{v}>$, que, segundo a Academia, debían abandonar toda "promiscuidade" de tal forma que $<\mathrm{u}>$ se usase sempre como vocal e $<v>$ sempre como sonsoante, "y esto sin la diferéncia y distinción que à cada passo se halla en qualesquiera obras impressas, de usar de la $V$ cerrada en el princípio de las palabras, sin atender à si es consonante, ò vocál: porque en qualquiera parte que se hallen, yá sea en el medio, yá en el princípio, la que es vocál siempre es vocál, y la que es consonante es consonante: y assi no hai fundamento para confundirlas" (RAE 1726-1739: I, p. LXXI). Pois ben, o que a RAE criticaba e proscribía en 1726 seguía operante nos fragmentos galegos do Theatro Moral de 1731, aínda que non, salvo nunha excepción, nas súas correspondentes transcricións decimonónicas: vna (1. 4; AI unha), vn (1. 8), vn (1. 12; AI un).

O mesmo criterio de especialización foi o que se adoptou para $<\mathrm{i}>$ e $<y>$ (RAE 1726-1739: I, pp. LXXI-LXXI, LXXXIV): prescindindo do uso etimolóxico do 
$<\mathrm{y}>$, o primeiro grafema utilizaríase con valor vocálico (misterio, aire) e o segundo con valor consonántico, que era o que tiña naqueles casos en que "hería vocal" (ayuda, yace). Exceptuaríanse desta norma a conxunción y, polo uso establecido de escribila así, e os nomes rematados en ditongo decrecente con [j] (ley, rey, comboy), para mante-la cohesión entre singular e plural e tendo en conta que en leyes, reyes ou comboyes $\mathrm{o}<\mathrm{y}>$ si representaba unha consoante. $\mathrm{O}$ texto que estamos a analizar non acusa tampouco a aplicación desta norma no referente ós casos dos ditongos decrecentes, xa que, aínda que entre as voces galegas se len deijese (1.18) e pois (1. 6), tamén se len, e son maioría deyjo (1. 11; AI deijo), fay (1. 18), feyto (1. 18), primeyro (1. 6) moytos (ls. 7, 20). Por outra parte, temos cinco casos de mais (ls. 4, $6,17,19,21)$ por soamente dous de mays (ls. 11, 12), e nos treitos en castelán encontramos Reyno (1. 10). O uso establecido para a conxunción copulativa $y$, admitido como xa irremontable pola RAE, é aceptado para a realización asilábica que adopta a conxunción copulativa galega en contexto antevocálico: y en canto (ls. $5,7)$. En realidade, estamos ante unha cuestión que demorou moito en chegar a situarse nos termos en que hoxe está establecida na ortografía castelá, xa que tivo que vence-la dura resistencia que opoñían uns hábitos escriturarios profundamente arraigados. A Real Academia Española tivo que volver e persistir durante moito tempo no uso de $<\mathrm{y}>$ para ley, ayre, etc. e, mediado o século XIX, aínda non se atrevía a reprobar Reyna en atención ó uso xeneralizado de escribir así esa palabra (RAE 1850: 10). O uso revelouse, sen dúbida, como unha das pexas que máis dificultaban o avance cara a unha ortografía castelá rigorosa, establecida de acordo co respecto sen excepcións a criterios razoables e claramente expresados. Ningunha outra razón máis cá súa tiranía foi a que coutou o ánimo dos primeiros académicos da institución cando decidiron que debería escribirse oy, e non hoy: "Viene del Latino Hodie, por cuya razon parece se debia escribir con $h$, pero el uso comun lo escribe sin ella" (RAE 1726-1739: III, 68). Estou certo de que aquí, no respecto ó uso (castelán) e no respecto á RAE, está tamén o motivo polo que Pablo Mendoza de los Ríos escribiu oxe (ls. 13, 18) en 1731.

En posición intervocálica a consoante nasal velar represéntase mediante $<n>$, seguramente tamén por emulación do emprego castelán do mesmo grafema para a consoante nasal alveolar situada no mesmo contexto: vna (1. 4; AI unha), ninguna (1. 16). Neste aspecto, Mendoza de los Ríos mantívose alleo á liña de consolidación do emprego do dígrafo $<\mathrm{nh}>$ para representa-la consoante nasal velar intervocálica que se observa nos escritos galegos do século XVIII, con Sarmiento como excepción máis consciente e significativa (cf. Mariño Paz 1999: 294-295). Mais cómpre recoñecer que en realidade non existía no século XVIII unha moderna tradición escrituraria galega á que acollerse, nin tampouco unha comunidade de escritores en galego que puidese chegar a constituír tal tradición. Non era en absoluto escritor en galego o fundador e presidente da Academia Compostelana de 1731, como tampouco o eran realmente aqueles dos que hoxe coñecemos unha 
única e breve composición no noso idioma ou pouquiña cousa máis (Noguerol y Camba, Anselmo Feijoo, Plácido Feijoo...). Por todo isto, é completamente natural que faltase unidade gráfica no conxunto da producción escrita galega da época e completamente natural tamén que, conscientemente ou por simple ignorancia do que outros xa fixeran, Mendoza de los Ríos se valese do grafema $<$ n $>$ para casos en que hoxe utilizamos $<\mathrm{nh}>$.

Salta á vista, en fin, que no terreo da grafización o autor do Theatro Moral actuou máis como elo da cadea de transmisión dos usos establecidos na materia durante séculos ca como coñecedor e cumpridor dunhas normas académicas que á altura de 1731 estaban aínda moi lonxe de seren unanimemente acatadas e observadas, pois, entre outras cousas, a prohibición de que nas escolas públicas do Reino de España se ensinase outra ortografía que non fose a disposta pola Real Academia Española non chegaría ata o 24 de abril de 1844. Dada a similitude dos sistemas fonolóxicos galego e castelán e a máis ca probable desproblematización con que Mendoza contemplaría o problema ortográfico galego, resulta natural que, coma outros, transplantase sen titubeos para o galego moitos dos usos centenarios xa consagrados en castelán.

Máis alá da vestimenta gráfica, que obedece a leis propias e peculiares, coido que son fundamentalmente dúas as chaves que permiten entender e explica-la maioría das formas e estructuras lingüísticas que conteñen as liñas en galego do Theatro Moral: en primeiro lugar, a intención de lle conferir autenticidade popular á fala do compañeiro do fundador e presidente da Academia Compostelana, e, xunto a isto, o castelanismo, imputable en parte á orixe burgalesa do escritor e en parte tamén ó grao de interferencia, especialmente lexical, que á altura do primeiro tercio do século XVIII sufriría o idioma galego, e nomeadamente o das camadas sociais máis expostas a esta erosión (clérigos, letrados, universitarios, soldados, emigrantes temporeiros, etc.).

Canto á primeira das chaves, comecemos por subliñar que Mendoza de los Ríos caracteriza o compañeiro de pousada que fala con el como un fidalgo montañés "tan rancio en lo ydalgo como en lo codio" (Mendoza de los Rios 1731: "Prólogo, o lo que fuere", s.p.). Séguese de aquí non só a consecuencia de que tal tipo humano debería representarse expresándose en lingua galega (consecuencia probablemente trivial para os galegos de 1731, pero interesante e digna de atención para os do ano 2000), senón tamén a conveniencia de que o seu galego tivese unha patente coloración popular. Tal coloración é o resultado de combinar recursos tales coma a falta de fixación das vocais átonas, que tenden a elevarse, a miúdo por harmonización (/e/ > /i/: Filigrisia, 1. 13; /o/ > /u/: Putriño, ls. 8, 12; Putriñas, 1. 13; curtesia, 1. 17), aínda que tamén hai algún caso de descenso ou perda de altura, probablemente por asimilación (/i/ > /e/: emprentar, 1. 5). Na mesma dirección apuntan a alternancia entre falsos prefixos que vemos en Academia (ls. 7, 18) e Encademia (1. 5) ("ou como se chama"), o [j] antihiático de creiame (1. 18), a 
eliminación da consoante implosiva dos grupos consonánticos heterosilábicos dos cultismos (praticar, 1. 17; esprican, 1. 17) 14 $^{14}$ a preferencia pola combinación con consoante vibrante no caso dos grupos consonánticos homosilábicos (esprican, 1. 17) ou a disimilación entre líquidas (deprendelle, 1. 7). En principio poderíase integrar no mesmo arquivo a vacilación entre coñocer (1. 11), a solución máis común no galego medieval derivada rectamente de COGN_SCERE (cf. TC: II, 355), e a antigamente máis rara coñecer (coñeso, 1. 12); pero, máis ca nunha disimilación $o \ldots o>o \ldots e$ ou nunha asimilación $o \ldots e ́$ > $>e . . e ́$, creo que para explicar este cambio hai que pensar na atracción analóxica probablemente exercida pola grosa nómina dos verbos incoativos galegos rematados en -ecer (adormecer, anoitecer, escurecer...), ante a que pouca resistencia podería opoñe-lo rarísimo -ocer de coñocer.

Os coloquialismos afellas (1. 5) e aquestado (1. 6) achegan tamén a súa contribución á tarefa de lle dar aire popular á forma de falar do fidalgo montañés. Dado que me parece menos coñecido có primeiro dos dous mencionados, detereime nesta ocasión na consideración histórica do coloquialismo aquestado. Hoxe en día son aquel e aquela os demostrativos galegos que convertemos en substantivos cando queremos referirnos imprecisamente a algo para o que non atopamos ou non queremos utiliza-la denominación exacta; de aquel e aquela derivan o verbo aquelar e o adxectivo aquelado. Mais no século XVIII tamén se empregaban co mesmo valor aqueste, aquesta, aquestar e aquestado, segundo deducimos non só da documentación que rexistramos no Theatro Moral de 1731, senón tamén da información que reuniu o Padre Sobreira. Nas papeletas do bieito de Beade lemos, despois de aquelado e aquelar(se), o seguinte:

AQUESTA. S.f. La calidad de alguna cosa que no se quiere nombrar, como: Fulano hé bò, pero ten unha aquesta que...

AQUESTA. S.f. Ribadavia. Falta, pero, calidad mala. Fulano he bo bó mozo, sin aquesta ningunha.

AQUESTADO, DE. P.p. de Aquestar.

AQUESTAR. V.a. Ribadavia, que significa hacer una acción que no se quiere nombrar por su nombre o no se acierta, como aquestar los santos, por adornarlos.

AQUESTAR. V.n. Ibi.

AQUESTARSE. V.r. Ibi.

AQUESTE, TA. S.m. y fem. Ribadavia. Aquella cosa que no se quiere, o no se acierta a decir (Sobreira 1979: 244).

14 Así e todo, convén non esquecer que antes do triunfo das reformas académicas do século XVIII tamén eran comúns no castelán escrito formas do estilo de efeto, acetar, dino, ecelente, ou do Letor da liña 2 do texto de Mendoza de los Ríos (cf. Penny 1991: 91-93; Lloyd 1993: 557-559). 
Aquestar e aquestado (xunto a aqueste e aquese, que se dan como "anticuados") aínda se incluíron no Diccionario gallego-castellano da Real Academia Galega (1913-1928: 208), pero adivíñase o esmorecemento en que naquela época estarían estas voces ó observar que nesta obra non se fixo definición de aquestar, senón que desde esta entrada se remitiu directamente para a última acepción de aquelar. Mais, así e todo, ilustrouse a entrada aquestado cuns versos dos Cantares gallegos (1911) de Manuel Leiras Pulpeiro:
Moitiñas bágoas, moitiñas
choréi doente d'aquela;
que, antes que verme aquestada, morrer cen veces quixera.

É certo que tamén se detecta a presencia de aqueste e aquestar en diccionarios máis recentes coma o de Eladio Rodríguez González (1958-1961) e o de Xosé L. Franco Grande (1968), pero sabemos que estes autores recolleron moitas voces de obras lexicográficas anteriores sen as someter á debida crítica, de tal modo que nos seus traballos se encontra mesturado o léxico do galego actual co léxico do galego doutras épocas que hoxe, e desde hai moito tempo, está xa abandonado. Ben claro fala a este respecto o feito de que estes dous autores digan de aqueste que "tiene poco uso" (por non diciren "ningún" ou "practicamente ningún") e que de aquestar remitan para aquelar. Mesmo chegan a rexistrar aquese, do que afirman que "apenas se usa", cando simplemente deberían dicir que hoxe non se usa ${ }^{15}$ e que xa na Idade Media era rarísimo en galego.

Ó meu parecer, a sorte destes usos de aqueste, aquesta, etc. estivo inevitablemente ligada á propia sorte que correron estas mesmas formas como demostrativos. No eixe temporal, o abandono xeneralizado dos demostrativos reforzados de primeira persoa (os de segunda xa eran rarísimos na lingua medieval) foi con certeza moi anterior tanto ó do seu uso como substantivos con significado impreciso coma ó do verbo e o adxectivo que deles derivaron. Baste con apuntar que, segundo Maia (1986: 688), na documentación notarial que ela explorou os demostrativos reforzados de primeira persoa ocorren con algunha frecuencia durante o século XIII, pero son xa relativamente raros no século seguinte e non aparecen no XV e no XVI. É certo, sen embargo, que nos Miragres de Santiago, que se poden datar entre finais do XIV e principios do XV, aínda temos unha boa presa de rexistros destes demostrativos reforzados: aqueste

${ }^{15}$ Creo que os datos que ofrece o Atlas Lingüístico Galego para a lingua do último cuartel do século XX non invalidan esta afirmación. Segundo o ALGa 2 (mapas 223-230), empréganse as formas reforzadas aqueste e aquestes, en concorrencia con este e estes, na parroquia de Cadafresnas (concello leonés de Corullón); canto ó uso de aquesta(s), aquesto, aquese(s), aquesa(s) e aqueso no mesmo lugar (en suposta concorrencia con esta(s), esto, ese (s), esa(s) e eso), os mesmos investigadores do ALGa dubidan da exactitude da resposta. 
(MS, 25, 181), aquestes (MS, 111, 181), aquestas (MS, 130), aquesto (MS, 198, 203, 212, 229, 232). Mais, así e todo, os datos con que contamos parecen indicar que xa durante o século XV tales formas foron caendo no desuso en galego e converténdose en simples reliquias do pasado que poderían aceptarse nun texto relixioso coma os Miragres de Santiago, pero xa non, salvo posibles excepcións, nos instrumentos notariais. Non moi distinta debeu de se-la historia do declinio destes demostrativos reforzados en portugués, onde, con todo, aínda se rexistran nalgúns autores precamonianos como Gil Vicente e tamén no propio Camões (cf. Ali 1966: 99; TC: II, 157). Os datos do castelán veñen ó encontro dos do galego e do portugués e contribúen por tanto a marcar unha tendencia observable nunha ampla zona iberorrománica: no romance nacido en Castela aqueste e aquesse utilizáronse en obras literarias ata o século XVII, pero que seguramente desapareceran da fala espontánea moito antes (cf. Lloyd 1993: 560). Finalmente, é congruente con todo isto que ó final do século XVIII Sobreira (1979: 243) recollese aquel como demostrativo galego en uso (coma hoxe), mentres que para aqueste só deixaba rexistrado o seu emprego como substantivo con significado impreciso. A cronoloxía do proceso galego, por conseguinte, semella transparente: do aqueste demostrativo saíu o seu uso como substantivo e os derivados verbal e adxectivo correspondentes ${ }^{16}$; o aqueste demostrativo abandonouse case por completo antes de remata-la Idade Media, pero mantívose durante máis tempo o seu uso como substantivo e tamén o dos seus derivados verbal e adxectivo; finalmente, estes últimos usos puideron chegar mesmo ata o século XX, mais acabaron por ser abandonados ó faltárlle-lo apoio da base demostrativa aqueste e probablemente porque estaban en situación de suma debilidade antre aquel, aquelar e aquelado, que podían asumi-los mesmos valores ca aqueste, aquestar e aquestado e ademais seguiron contando ata hoxe coa apoiatura do aquel demostrativo.

Un recurso gramatical que contribúe poderosamente a conferirlle autenticidade e sabor coloquial á fala do fidalgo compañeiro de Mendoza é o dativo de solidariedade. Dado que a conversación reproducida no texto nace nun ambiente distendido e de familiaridade entre os interlocutores, resultan completamente naturais os seguintes usos do dativo de solidariedade, expresado mediante o clítico de cortesía lle:

eu non lles quito à sua fidalguia, mays tampouco deyjo de coñocer, que lles basta para chegar à suas Casas saberlle montar vn Putriño (ls. 10-12);

16 A primeira documentación destes usos que eu coñezo é a contida no Theatro Moral de Pablo Mendoza de los Ríos. Sen embargo, teñen que ser moito máis antigos. Que non contemos con rexistros anteriores a 1731 non é máis cá lóxica consecuencia da pobreza tipolóxica da nosa documentación medieval (carente case por completo de textos que reproduzan rexistros coloquiais ou que se aproximen a eles) e da escaseza da documentación en galego dos séculos XVI, XVII e XVIII. 
os seus Academicos, como lle aprenden para Letrados, ninguna cousa podian desear mais, que falar ben, è praticar curtesia, que es ò que Vustedes esprican (ls. $16-17)^{17}$.

A rareza dos contextos coloquiais dentro da documentación galega medieval abre poucas posibilidades para a detección de dativos de solidariedade en textos de entre os séculos XIII e XVI. Non é completamente incontrovertible o coñecido exemplo da Crónica Xeral Galega (ca. 1295-1312), porque se pode interpretar como dativo de interese:

Rey, nõ as por que teer nẽhũu destes que comigo som presos, que por mj̃ soo aueras quantos y som, et nõ lles faças nẽhũu mal, ca elles nõ che am y culpa nẽhũa (TC: I, 130).

A penuria documental dos nosos "séculos escuros" non nos proporciona máis ca dous exemplos tirados de textos do século XVII, xa sinalados por Freixeiro Mato (2000: 140):

- Esa èche treta formada, / y abes de quedar debaijo / coa bosa teima inchada ( $A$ contenda dos labradores de Caldelas, 1 v., ca. 1668-1671).

- O Mariscal Pedro Pardo de Cela Saavedra [...] foy vendido por seos criados en quen se fiava, no ano do mil è catrocentos è oytenta è tres. Son bos os siguentes. Vn Fernan Garcia Tafornelos, natural das Pontes de Garcia Rodriguez... (Relazón da carta xecutouria, p. 137, 1674) ${ }^{18}$.

Despois de 1731, ano de publicación do Theatro Moral de Mendoza de los Ríos, utilizouno con xenerosidade Frei Martín Sarmiento no Coloquio de 24 gallegos rústicos (ca. 1746), onde o ton distendido e a familiaridade entre entre os interlocutores configuran un marco moi axeitado para o seu uso. O recurso emprégase con profusión non só nas coplas atribuíbles ó Padre Sarmiento (da 1 á 1.201), senón tamén nas debidas ó seu anónimo continuador (da 1.202 á 1.308). Ofrezo unicamente tres casos tirados desta obra:

No dia catorce / dò mes e ano mesmo, / que foy quinta feira, / se bem che me lembro! (copla 267).

Eche tan pacifigo / é brando á desejo / que nèl teràn todos / hum par verdadeiro (copla 1.041).

En Monforte, digo, / ayvos un combentò / donde viven frades / do señor San Bieito (copla 1.243).

${ }^{17}$ Discutibles, por interpretables como dativos de interese, parécenme estoutros dous casos: "Vuste [...] soñou vna cousa dormido que eu non lla discurrira desperto" (ls. 3-4);"digalle (pois està mais aquestado en essas cousas, ) que primeyro è saber falar Español, que deprendelle Frances” (1s. 6-7).

18 Sobre a cronoloxía da Relazón da carta xecutouria cf. Mariño Paz (1997b: 8). 
Son tamén abundantes os rexistros que se encontran nos textos dos séculos XIX e XX e hoxe o dativo de solidariedade continúa sendo un recurso moi utilizado e descrito en tódalas gramáticas.

É evidente que carecemos aínda dun estudio histórico en profundidade do dativo de solidariedade. Tal estudio, ó meu modo de ver, non poderá de ningunha maneira desentenderse do feito de que o galego, fronte a outros romances, chegase a desenvolver dúas expresións clíticas de segunda persoa singular: te e che. A este respecto, parécenme moi dignas de atención as ideas expostas por Varela Barreiro (1997: 324-325). Para este autor, o estudio do galego escrito nos séculos XIII, XIV e XV apunta a que neste tempo te "conserva practicamente intacto o valor como marca de CD pero [...] cede terreo no espacio do CI, basicamente ante o empuxe da forma che" ${ }^{\prime \prime}$. Coida ademais Varela Barreiro (1997: 329-338) que para explicalo distinto comportamento do galego e o portugués comúns hai que pondera-lo feito de que semella que en xeral a forma che se mantivo como CI alí onde se mantivo tamén o dativo de solidariedade (no galego común e no galego cheísta) e chegou a perderse alí onde o dativo de solidariedade non se consolidou (no portugués común e no galego teísta); por tanto, é posible que "che chegase a asentar como elemento funcional no sistema clítico porque entre os seus cometidos estaba o de marca-la función do dativo de solidariedade" (p. 338). Sería necesario, para podermos afinar e ampliar esta análise, facer aínda un pormenorizado estudio histórico da evolución do uso dos pronomes galegos te e che que poida ofrecernos unha cronoloxía dos estadios do seu desenvolvemento tanto ata o moderno sistema común coma ata o denominado "cheísta"; é necesario tamén analizar nese estudio os distintos condicionantes gramaticais ou lexicais que en determinados contextos favorecerían ou retardarían o avance de che e, se fose posible, conviría apuntar datos que deitasen luz sobre a dialectoloxía histórica destes usos pronominais en galego. No marco deste amplo estudio, que aquí obviamente non podo senón proxectar, terá que encontrar cabida e explicación o recurso do dativo de solidariedade.

Respecto da forma pronominal de respecto Vuste (1s. 3, 10, 18, 19), Vustede (1. 5), Vustedes (1. 17), non sei de rexistros galegos anteriores a estes de 1731, pero si recordarei que, logo dun hiato en branco de arredor dun século, aparecen vosté e vostede nalgúns textos dialogados de 1823 e 1836 (cf. Mariño Paz 1991: I, 444-

${ }_{19}$ Para Varela Barreiro (1997: 325), “do lixeiro predominio de Te na Traducción da Crónica General... pásase ó lixeiro predominio de Che na Crónica Troiana e chégase, finalmente, á clara imposición de Che nos Miragres de Santiago. Do conxunto de obras en prosa, son estas tres as que mellor representan os valores medievais do galego, polo cal podemos afirmar que entre os séculos XIII e XV cristaliza definitivamente a oposición CD / CI na $2^{\mathrm{a}}$ persoa singular do clítico. Os Cancioneiros non fan senón confirmalo e ó mesmo tempo poñen de manifesto, sobre todo no caso das Cantigas de Santa María, que no século XIII a forma Che xa conseguira introducirse con bastante forza no sistema clítico". 
445). Son igualmente tardías as primeiras documentacións que Corominas e Pascual dan en castelán para os descendentes de vuestra merced (principios do século XV): vuasted (1617), vuested (1635), vusted (1619), vusté (1645); para o você portugués resulta inaceptable, por excesivamente moderna, a data de 1813 que ofrece Cunha (1994), mais en todo caso pódese concluír que tamén en Portugal se chegou tardiamente a esta forma de tratamento. Nunha análise superficial poderíase afirmar que no vuste(de) do Theatro Moral non temos senón un exemplo máis de elevación $/ \mathrm{o} />/ \mathrm{u} /$ en posición pretónica, mais neste caso paréceme máis convincente acudir á explicación por interferencia. Coido que vostede, vosté, vustede e vusté se deben entender fundamentalmente como resultantes de contraccións fonéticas de vuestra merced debidas ó extraordinario uso que desta forma de respecto se faría, pero coido que non poden provir dunha evolución regular dunha hipotética fórmula galega coma vosa mercé ou vosa mercede. Ora ben, o que si me parece necesario é admitir unha certa contaminación galeguizadora que, cando menos, explicaría a terminación -ede e tal vez tamén a vocal de vost -. En todo caso, estamos unha forma de tratamento tardía, carente de tradición non contaminada en galego, probablemente importada e non forxada ou modelada autonomamente. Desde logo, que o seu primeiro rexistro galego estea nas liñas escritas polo burgalés Pablo Mendoza de los Ríos non é nin moito menos unha garantía de que vuste(de) ou voste(de) sexan formas xeradas autonomamente polo galego, senón máis ben todo o contrario.

Estas reflexións sobre vusté introdúcennos de cheo na exposición das cuestións relativas á segunda das chaves que antes mencionei como necesarias para comprendérmo-la lingua das liñas que estamos a analizar: o castelanismo. Nunha época coma a do primeiro tercio do século XVIII, en que o continxente de usuarios habituais ou permanentes do castelán era aínda pouco numeroso en Galicia, a interferencia debía de afectar fundamentalmente ás camadas sociais máis expostas ó contacto co castelán (nobres, burócratas, soldados, emigrantes temporais, etc.), mentres que para grande parte da poboación tal influencia debía de ser moito máis superficial e afectaría unicamente, ou principalmente, a certos sectores do vocabulario. Tense dito moitas veces, e con razón, que o léxico relixioso foi un dos máis antiga e intensamente erosionados pola castelanización, e xustamente nas liñas galegas do Theatro Moral temos un castelanismo relixioso, Filigrisia (1. 13), para o que contamos con bastante documentación medieval, aínda que sospeito que nalgúns casos, e nomeadamente nos máis antigos (de finais do século XIII), puido haber contaminación latinizante (de FILI) máis ca influencia castelá, aínda leve naquel tempo. Algúns dos testemuños medievais dos que dispoño son os seguintes: filigresia (Maia 1986: 208, ano 1298, e 211, ano 1299; USC, p. 337, ano 1433), feligresia (Maia 1986: 243, ano 1506; LCP, p. 111, ano 1437), filigrisia (USC, p. 250 , ano 1377). Con todo, nos documentos medievais empréganse comunmente as solucións galegas, que aínda ocorren na Contenda dos labradores de Caldelas (ca. 
1671), anterior nuns sesenta anos ó Theatro Moral de Pablo Mendoza de los Ríos: freguisia (Contenda, 1 v.), freigisia (Contenda, 3 v.).

En principio, semellan tamén castelanismos Putriño (ls. 8, 12) e Putriñas (1. 13), pero o certo é que, como xa observou Lorenzo (TC: II, 1033), nos textos galegos e portugueses potro alternou sempre coa forma herdada poldro (<*PULLITRU). Ós testemuños achegados por este autor pódenselles agregar estoutros tres tirados de instrumentos notariais editados por Clarinda Maia: poldo (Maia 1986: 133, ano 1281), poldro (Maia 1986: 133, ano 1281) e "Outeyro dos poldros" (Maia 1986: 174 , ano 1473). Ó meu modo de ver, potro produce desconcerto porque se trataría dun castelanismo que, por unha parte, sería moi antigo e, por outra, porque se integra nun campo semántico (o do gando) que en principio semella moi pouco exposto a unha castelanización tan remota.

Fronte a isto, non me inspiran ningunha dúbida os casos de desear (1. 17) e supo (1. 12; AI soupo). Para o primeiro, en medio da inapelable maioría medieval de desejar, soamente podo mencionar un rexistro máis antigo có das liñas de Mendoza de los Ríos: trátase do deseardes dun documento de San Salvador de Lourenzá de 1442 (Maia 1986: 109). Con este rexistro de 1731 debido ó autor burgalés contrastan o desejo e desejan do Coloquio de 24 gallegos rústicos de Frei Martín Sarmiento (cf. Mariño Paz 1997a: 102), un home que, amais de te-lo galego como primeira lingua adquirida, posuía grandes coñecementos da nosa lingua medieval e estaba animado por un notable espírito de depuración dos castelanismos. Do radical sup- para o tema de perfecto de saber non coñezo documentacións anteriores á do Theatro Moral, xa que nos textos medievais o que se detecta, que eu saiba, é sempre soub-. Creo que no século XVIII sup- xa debía de ter algunha circulación, dado que se le non só nas liñas que estudio neste artigo, senón tamén nos versos de Sarmiento (xunto a soub- e soup-) e, xa no século XIX, nas Proezas de Galicia (1810) de José Fernández Neira (cf. Mariño Paz 1991: I, 639).

Os derivados cultos de correr teñen, como é de supoñer, entrada tardía nos dous romances iberorrománicos occidentais que viviron como época de consolidación a transición da Idade Media á Idade Moderna. Para o portugués, Cunha (1994) sitúa a primeira documentación de discorrer (< lat. DISCURRERE) en 1572, a primeira de concorrer ( $<$ lat. CON-CURRERE) no século XV, a primeira de encorrer 'incorrer' (< lat. INCURRERE) no XIV, a primeira de ocorrer (< lat. OCCURRERE) no XV, tamén no XV a primeira de recorrer (< lat. RECURRERE) e só no XIX a primeira de transcorrer (< lat. TR_NS-CURRERE). Para o castelán, Corominas e Pascual sinalan o século XV para discurrir (pero Juan de Valdés aínda di no XVI que este verbo se debería introducir no castelán), tamén o XV para concurrir, o ano 1490 para incurrir, ca. 1440 para ocurrir e 1490 para recurrir, mentres que de tra $(n)$ scurrir ofrecen a información de que falta aínda na edición do diccionario da RAE de 1843. O galego, pola súa parte, carece de 
tradición medieval para estes cultismos, polo que non nos pode estrañar que a primeira documentación dunha forma do verbo descendente de DISCURRERE que creo se pode mencionar (o discurrira da liña 4 do texto aquí analizado) se acollese, como o fixeron en castelán os derivados cultos de correr, á terceira conxugación.

O Instituto da Lingua Galega e a Real Academia Galega (1995: 131) expoñen, a meu parecer con acerto, os factores que nestas incorporacións xogaron a prol da segunda ou da terceira conxugación: a favor da terceira actuou a súa maior productividade (de feito incorporáronse a ela a maioría dos verbos cultos casteláns e portugueses procedentes da segunda, terceira e cuarta conxugacións latinas), así como tamén o feito de que nos tempos en que hai coalescencia morfolóxica entre a segunda e a terceira prevalecen as desinencias propias da terceira; e a prol da segunda operou "a existencia dun verbo patrimonial próximo, pola forma e polo significado, á base latina da que proceden os derivados cultos (combater $=$ bater, recorrer $=$ correr $)$ ". Así e todo, coido que no caso do idioma galego houbo unha circunstancia extralingüística ou sociolingüística que prevaleceu sobre os devanditos factores morfolóxicos; refírome á vía de transmisión pola que lle chegaron estes derivados cultos de correr, romper ou verter, que non foi outra cá da que foi (e é) a súa lingua teito desde o final da Idade Media ata o final do século $\mathrm{XX}$ : o castelán.

As liñas que son obxecto de estudio deste artigo conteñen polo menos dous sintagmas ${ }^{20}$ en que o posesivo non vai acompañado de ningún determinante sen que concorra ningún dos factores que, no galego de finais do século XX (cf. Álvarez / Regueira / Monteagudo 1986: 152-153), poden explicar tal omisión:

eu non lles quito à sua fidalguia, mays tampouco deyjo de coñocer, que lles basta para chegar $\grave{a}^{21}$ suas Casas saberlle montar vn Putriño (ls. 10-12);

saque ò seu Libriño à mais seus Cartiños ${ }^{22}$, è si pode fagase Crego (ls. 19-20).

Sintagmas con posesivo non acompañado de determinante perfectamente equiparables a estes aparecen con moita frecuencia no Coloquio de 24 gallegos rústicos do Padre Sarmiento ("dirà teus defeutos", 141.4; "bourar teu coiro", 1080.3 ; etc.), onde tamén se detectan case a cada paso usos e colocacións dos pronomes átonos que para os lectores do ano 2000 resultan inaceptables. Xa indiquei en ocasións anteriores (cf. Mariño Paz 1995: 70-71, 72; Mariño Paz

\footnotetext{
${ }^{20}$ Hai un terceiro sintagma en que sospeito que sucede o mesmo, mais non podo aseguralo porque a falta de regularidade na acentuación de monosílabos non permite saber con certeza se trala forma gráfica à está só a preposición $a$ ou ben está a contracción desta preposición co artigo $a$ : "y en canto à montar Cabalos, bastalles à moytos da Academia vn Putriño para chegar à sua Aldea" (ls. 7-8).

${ }^{21}$ AI ás.

22 ANM a mais os seus cartiños.
} 
1997a: 97) que unha explicación de tales estructuras na obra poética en galego de Frei Martín Sarmiento debe valora-lo dato de que, quitando as viaxes á súa terra de 1725,1745 e 1754 e os contactos con galegos que puido establecer en Madrid ou noutros lugares despois de 1710, o monxe pontevedrés viviu fóra de Galicia e en ambiente lingüístico non galego desde os seus quince anos, é dicir, desde 1710. Con todo, esa explicación non se pode elaborar en ausencia dun estudio histórico sobre a combinatoria do posesivo co artigo ou outro determinante dentro da frase nominal galega, nin tampouco sen reparar en que as esixencias de ritmo e medida puideron inducir a non poucos poetas a permitirse no verso certas licencias gramaticais que de ningunha maneira admitirían na prosa. Ora ben, este último argumento, que podería aducirse para interpreta-los casos detectados no Coloquio do Padre Sarmiento, non vale por razóns evidentes para os sintagmas sinalados nas liñas en galego do Theatro Moral, que, amais de non estaren condicionadas polas esixencias propias do verso, reproducen un rexistro linguístico que evidentemente se pretende próximo á oralidade, se non pegado a ela.

Unha pequena aproximación ó tipo de traballo histórico que antes mencionei como necesario fíxoa xa Silva Domínguez (1993), quen advertiu que na lingua literaria do século XIX se observa que a frase nominal con posesivo leva maioritariamente un artigo á súa esquerda, pero que hai ata un $35 \%$ de casos en que se usa a estructura non articulada. Segundo a devandita autora, a escolla dunha ou outra estructura parece vir condicionada por factores estilísticos ou semánticos (o significado do substantivo determinado polo posesivo), pero non por principios estrictamente sintácticos. No Divino sainete (1888) de Manuel Curros Enríquez chama a atención un caso en que o cuantificador universal todo se une directamente ó posesivo dentro do sector determinativo da frase, sen ningún artigo:

Todos teus bens recollidos

ceibados ós catro ventos

os ósos dos teus maiores,

afogados teus lamentos.

Segundo Silva Domínguez (1993: 138), a estructura "todos teus bens recollidos" está "máis relacionada coas licencias propias do código poético que coa gramática da época" e coido, pola miña parte, que idéntica afirmación é válida para o "afogados teus lamentos", xa que introducirlle a este verso o artigo conduciría a darlle unha medida inaceptable de nove sílabas. Ademais, que a gramática da segunda metade do século XIX esixía o artigo nestes sintagmas é o que creo que indican tamén as correccións que Antonio de la Iglesia nun caso e Antonio Neira de Mosquera no outro lles fixeron ós dous sintagmas do texto de Mendoza de los Ríos antes transcritos: "para chegar ás suas Casas", "a mais os seus cartiños". 
De acordo con Silva Domínguez (1993: 139-144), a reducción porcentual da posibilidade de que o posesivo apareza como determinante único dentro da frase nominal é considerable en Devalar (1935) de Otero Pedrayo (24'50\% dos casos) e máis aínda en Os dous de sempre (1934) de Castelao (11'56 \%); na mesma liña, con algunha excepción coma a de Álvaro Cunqueiro, parecen continua-las obras de escritores posteriores. Sería preciso debullarmos caso por caso en cada unha das obras mencionadas para quedarnos unicamente con aqueles que non se poden explicar por factores como a existencia dunha construcción vocativa, a presencia dun substantivo de parentesco como núcleo da frase nominal ou outros que puidesen dar razón da omisión dun determinante acompañando o posesivo. Así e todo, tras desta magra exposición de datos albíscase na literatura e na lingua galega dos últimos séculos unha tendencia cada vez máis acusada a ir evitando as frases nominais en que o posesivo non vai acompañado dun artigo ou doutro determinante.

Ó meu modo de ver, da ponderación de todo o anteriormente exposto pódese tirala consecuencia de que resulta moi probable que as frases nominais con posesivo non articulado que se len nas liñas en galego do Theatro Moral de Pablo Mendoza de los Ríos se deban explicar pola orixe burgalesa do seu autor e, conseguintemente, polo seu precario dominio da gramática do galego en xeral, e sobre todo de aspectos tan sutís e complexos coma este que ata aquí nos ocupou.

$\mathrm{Na}$ liña 20 do texto que estamos a analizar aparece a voz cañòs, sobre a que ofrece cumprida información José Luis Alonso Hernández no seu Léxico del marginalismo del Siglo de Oro. Segundo Alonso Hernández, durante o Século de Ouro da literatura castelá cañón era palabra de "germanía" que se utilizaba con dúas acepcións:

$1^{\circ}$ Germ. Pícaro; el pícaro de cocina en la lengua de los valientes; criado de valiente.

"Llego la hora de cenar; vinieron a servir unos pícaros, que los bravos llaman cañones" (Buscón, II, 10).

$2^{\circ}$ Germ. Soplón, delator.

“Acogiose a toda calza / a dar el punto a la Mendez / el cañón de Mascaraque..." (QUEV[EDO])” (Alonso Hernández 1977: 174).

O Diccionario de Autoridades (1726-1739) da Real Academia Española asignáballe á "germanía" a acepción de cañón como 'soprón', mentres que da de 'pícaro' afirmaba que era propia de Galicia ${ }^{23}$ :

${ }^{23}$ Aínda que é a mesma en ámbolos casos, a cita ilustrativa de Francisco de Quevedo que dá a RAE difire non pouco da que ofrece Alonso Hernández: "Vinieron à servir à la mesa unos grandes picaros, que los Bravos llaman Cañónes" (Real Academia Española 1726-1739: 133). 
CAÑÓN. En Germanía significa el soplón: y en Galicia se llaman assi los pícaros perdídos, que no tienen oficio, ni domicilio (Real Academia Española 1726-1739: 132-133).

Poucos anos despois, por volta de 1745 e 1746, Frei Martín Sarmiento debeu de oír usar esta voz na viaxe que daquela fixo por Galicia, xa que a deixou anotada no seu Catálogo de voces y frases de la lengua gallega entre un conxunto de "Observaciones hechas después de que llegué a San Martín de Madrid a mi celda a 10 de Febrero de 1746": "Cañón y cañones. Son los pícaros de plaza en Galicia. Acaso de la voz calones (cañones) que eran como los vivanderos y esportilleros" (Sarmiento 1973: 362). Non contento con isto, o frade pontevedrés usou a palabra ata catro veces no seu Coloquio de 24 gallegos rústicos, sen dúbida coa intención de glosala por extenso no "comento" que concibiu como compañeiro indispensable do romanzón:

Non vistes ná vila / a vez que ay bateo / d'hum rico meniño, / é mais s'e primeiro, / botàr à apañota / no alpendre dò tempro / puñados de cartos / a os cañons è nenos? (Sarmiento 1995: 216).

Eu, mal pecadiño, / estaba temèndo / que me asoballasen / sen ningum remedio / os da gafualla, / cañons è labercos, / que daban moquetes, / couces è golpèos (Sarmiento 1995: 217).

Cantos lampantins, / cañons, galdrumeiros, / lanudos, felpudos, / congorzos, labercos! (Sarmiento 1995: 235).

Non quero áfrontarte, / nugallan, fedéllo, / encrenque, latante, / gorxon, godalleiro, / cañon, maricallo, / tiñoso, gafento, / lacazan, sarnoso, / mocoso, famelgo (Sarmiento 1995: 312).

Como pode comprobarse, os catro contextos do Coloquio en que Sarmiento inseriu a voz cañón avalan plenamente non só a explicación que dela deu el mesmo, senón tamén a información que ofrecía a RAE no seu Diccionario de Autoridades e a que en 1977 proporcionaba José Luis Alonso.

Descoñezo documentacións galegas de cañón anteriores á do Theatro de Pablo Mendoza de los Ríos e ignoro se xa para o Século de Ouro da literatura castelá esta palabra era xeralmente considerada un galeguismo en castelán. Despois dos rexistros localizados na obra do Padre Sarmiento cañón foi glosado por Antonio Neira de Mosquera na transcrición dun dos fragmentos en galego do Theatro Moral que fixo para o seu traballo titulado "La Academia Compostelana (1731)":

Esta palabra familiar del dialecto gallego equivale a malos. Es voz que se aplica en señal de repugnancia o menosprecio (Neira de Mosquera 1850: 194).

Certamente, a pesar de que afirmaba que se trataba dunha "palabra familiar del dialecto gallego", a explicación que para cañón apuntaba Neira de Mosquera era tan 
vaga que dá a impresión de que para el non era realmente unha palabra tan familiar como supostamente o era para os galegos en xeral. Semella máis ben que o que Neira fixo foi aventurarlle un significado vago e pouco comprometido que, sen definila con precisión, fose polo menos suficiente para proporcionarlle un sentido que, de tan amplo e vago que era, non podía resultar inadmisible. O propio feito de que a voz necesitase unha glosa é un indicio de que non debía de ser moi coñecida na Galicia de mediados do século XIX. É certo que a glosa podería estar dirixida ós posibles lectores non galegos do traballo, mais non creo que Neira de Mosquera esperase conseguir moitos lectores de fóra de Galicia para unha obra tan compostelá coma "La Academia Compostelana (1731)", incluída en 1850 nunha colectánea de Monografías de Santiago e publicada ademais en Santiago de Compostela.

Con posterioridade, cañón incluíuse no Diccionario gallego-castellano (19131928) da Real Academia Galega, pero teño a impresión de que non como voz recollida do uso na fala viva do primeiro tercio do século $\mathrm{XX}$, senón como palabra transmitida por vía libresca: despois de lle da-las acepcións de "el niño pequeño", "el muchacho travieso y pillo" e "pícaro, bribón, perdido", adúcense como ilustrativos os fragmentos do Coloquio do Padre Sarmiento que anteriormente transcribín eu (cf. Real Academia Gallega 1913-1928: 398). Transmisión libresca creo que hai que sospeitar igualmente para as entradas de cañón 'pillete' / 'pícaro' nos diccionarios de Rodríguez González (1958-1961) e de Franco Grande (1968); para min, a segunda acepción que da palabra dá Rodríguez González ten tódalas trazas de non ser máis ca unha suposición elaborada a partir dunha noticia antiga lida nalgunha obra de Manuel Murguía:

Niño pequeño o muchachote llegado a la pubertad que están acogidos en un asilo. En Santiago, según Murguía, había una casa que llamaban a casa dos cañós, que debió ser un hospital.

Ningunha das acepcións de cañón que ofrece Constantino García (1985) no Glosario de voces galegas de hoxe se pode identificar coas que aquí nos ocupan. Na miña opinión, á vista de todo isto podemos dicir que os distintos testemuños aquí aducidos proporcionan probas abondas de que cañón era unha palabra moi viva no galego e no castelán de Galicia entre o primeiro e o segundo tercio do século XVIII, e probablemente tamén bastante antes e bastante despois. Con todo, é probable que o seu uso estivese xa menos xeneralizado cando, mediado o século XIX, Antonio Neira de Mosquera escribiu o seu traballo sobre "La Academia Compostelana (1731)".

Ora ben, como atinadamente sinalou Pensado (1985: 97), este marxinalismo, por máis que acabase acantoándose en Galicia, non pode ser autóctono da nosa terra, xa que está construído sobre a voz castelá caña. Por conseguinte, debeu de chegar aquí na boca de individuos vinculados ós chamados "baixos fondos" ou a 
ambientes picarescos ou delincuenciais. Probablemente, a propia emigración temporal galega a terras de Castela funcionou como vehículo transmisor desta e doutras voces do seu xénero e rexistro.

Do anteriormente dito dedúcese que me parece digna de consideración a explicación etimolóxica que desta voz ofrece Pensado (1985: 97): "Entre rufianes [cañón] significaba 'soplón' y es un uso metafórico montado sobre caña (si fuese voz tradicional sería cana y su aumentativo canón) comparable al cañuto 'soplón, delator' o al dar cañuto 'delatar, avisar"'. Lémbrese que o uso de cañón por 'soprón' está aboado polo artigo lexicográfico do Dicconario de Autoridades da RAE transcrito máis arriba e ademais téñase en conta que no mesmo diccionario (p. 134) se recolle a mesma acepción para cañuto (e dar cañuto). Na mesma onda están exactamente cañutazo e dar cañutazo:

CAÑUTAZO. s.m. El soplo, ò chisme, que uno dice à otro con reserva y secréto: y assi dar cañutázo, es dar noticia y aviso de alguna cosa al que lo puede remediar (Real Academia Española 1726-1739: I, 133).

Paréceme verosímil que sobre caña ou cañuto 'instrumento ou utensilio polo que se sopra ou pode soprar' se formasen metaforicamente cañón e cañuto 'soprón' e, ademais, cañutazo e cañuto 'sopro'. Desde aquí cañon puido derivar doada, naturalmente, para 'pícaro'.

Fronte a isto, coido que resulta moi problemática a proposta de Corominas e Pascual, que, sen mencionaren o uso que desta voz fixeron Quevedo e outros clásicos casteláns, aventuran que se pode tratar dun derivado de calle no "castellano local coruñés" (con posterior cambio de palatais *callón > cañón), ou ben dun aínda máis problemático derivado romance de *CALLIONE (derivado do latín CALLIS 'camiño estreito'):

Emplea varias veces Sarm. en sus coplas cañón por 'muchacho travieso y pillo' y por 'pícaro, bribón, perdido' ([...] [y] define 'los pícaros de plaza en Galicia', comparándolo para su seudo-etimología con lat. calones 'ganapanes', 'bagajeros de ejército', voz sin descendencia en romance y que hubiera dado *caón): luego parece ser propiamente 'pícaro callejero', 'mozo de recados' y puede resultar de *callón, derivado de calle en el castellano local coruñés; a no ser que fuese antiguo y deriv. romance ${ }^{*}$ CALLIONE, que es más difícil, aunque podría defenderse si nos fijamos en callón 'raudal de agua más o menos impetuoso (Vall., Supl.) (a no ser que este salga de una combinación CANAL-ICUL-ONE *caellón) (Cor.-Pasc.: s.v.).

Hai demasiadas conxecturas, demasiados asteriscos, nesta hipótese, que ademais é presentada de maneira moi dubitativa e sen ningunha referencia ós rexistros da palabra na literatura castelá. A de Pensado, por contra, paréceme máis simple e fundamentada en datos moito máis seguros. 
A primeira documentación do adxectivo tonto de eu que teño noticia na historia da lingua galega é esta de 1731: tontos (1. 20). Os primeiros rexistros son tardíos tanto en portugués (o século XVI segundo Cunha) coma en castelán (1570 segundo Corominas e Pascual, que afirman que falta "en general en las fuentes medievales"). Este adxectivo de probable formación expresiva aparece en varios idiomas, románicos e non románicos, mais con diversos matices semánticos en cada un deles e con distinto grao ou frecuencia de uso. Non é improbable, á vista dos datos de que dispoñemos, que dentro da Península Ibérica funcionase o castelán como o seu elemento difusor. De feito, o moderno Diccionario da Real Academia Galega dirixido por Constantino García e Manuel González González (1997) considéraa unha voz non recomendable en galego, que debe abandonarse en favor doutras coma parvo, libres de toda sospeita.

Creo que tamén nos achamos ante o primeiro rexistro galego do substantivo mofa $(1.21)^{24}$, outra voz de probable orixe expresiva. O máis antigo en textos portugueses é, de acordo con Cunha, só do século XVII, aínda que non se debe esquecer que o verbo mofar xa se usou, polo menos, no XVI. Practicamente sucede o mesmo en castelán, segundo Corominas e Pascual: o primeiro caso coñecedido de mofar é de finais do século XV e o primeiro de mofa do XVI.

Xa para rematar esta parte do meu artigo, quixera facer algúns apuntamentos sobre diversas formas verbais.

Ocorren no texto tres formas do verbo facer ás que creo que paga a pena aludir, sequera brevemente. Temos, por unha banda, a P1 do presente de indicativo fago (1. 15) e maila P3 do presente de subxuntivo utilizada con valor imperativo: fagase (1. 20). Este tipo de formas, coñecidas xa no galego medieval e tamén no moderno portugués popular, acabaron por triunfar na nosa lingua sobre as antigas faço, faça, faças, etc.; a analoxía con digo, diga, digas, etc. e con trago, traga, tragas, etc. debeu de resultar determinante no desencadeamento e consumación deste cambio morfolóxico. Fagan está tamén nas coplas ó Apóstolo Santiago de Martín Torrado (ca. 1627). Canto a fay (1. 18) (antigo faz), é evidente que se tivo que xerar por analoxía cos xa antigos e tradicionais ay (de aver) e vay; xa dixen noutro lugar (Mariño Paz 1995: 87) que as primeiras documentaciós de fai que coñezo son xustamente do século XVIII, mais agora podo engadir este novo rexistro de 1731, algo anterior ós de María Francisca de Isla, Diego Antonio Cernadas y Castro, o Padre Sarmiento e o Padre Sobreira.

\footnotetext{
${ }^{24}$ Non parece digna de creto a lectura "A mofar, Don Lourenço, [a] chufar!" que algúns editores ofrecen para un verso dunha cantiga de Johan Garcia de Guilhade (cf. CBN, vol. 6, pp. 204-205; Lapa 1970: 337). Ás serias obxeccións paleográficas que cabe opoñer a tal lectura hai que lles agrega-la evidencia de que mofar e mofa parecen ser, sen dúbida, voces de aparición tardía no ámbito linguístico hispánico.
} 
Lense, entre as palabras proferidas polo compañeiro de Mendoza, as formas verbais deprendelle (1. 7) e aprenden (1. 16). Segundo Corominas e Pascual, aprender procede do latín APPREHENDERE 'coller, apoderarse de', mentres que deprender, vulgar en castelán desde o século XVI, debe de te-la súa orixe no latín DEPREHENDERE 'sorprender, atrapar'. Dá a impresión de que, se facemos caso omiso da estigmatización xeral que o noso idioma debeu soportar durante séculos, podemos afirmar que sobre o galego deprender non chegou a cae-la estigmatización que sobre este verbo caeu en castelán; de feito, deprender é admitido hoxe polo Diccionario da Real Academia Galega (García / González González 1997). Na lingua medieval o que máis se usaba era aprender, pero polo menos podo citar un rexistro de deprender contido na Geral Estoria do século XIV, onde curiosamente alterna con aprender:

Et pero que Abraã morou pouco en aquela terra, tanto ensynaua bem et agudamẽte, que estonçes aprenderõ os daly as artes lyberaes et as souberõ por Abraã queas deprẽdeo em Caldea onde as ouvo primeyramẽte et as ensynou el despoys ẽno Egyto (GE, p. 173).

\section{Uso oral e uso escrito do galego no século XVIII}

A pesar do abandono administrativo e literario e do descrédito xeneralizado en que o idioma galego foi caendo desde a segunda metade do século XV, a estructura socioeconómica da Galicia do Antigo Réxime non permitiu que se producise máis ca un mínimo progreso do proceso de aprendizaxe e uso habitual do castelán antes do século XIX. Se, por unha parte, os nutridísimos continxentes demográficos laboralmente integrados no sector primario non tiñan a penas posibilidades de promoción social nin, por tanto, necesidade de aprender e adoptar como propia a lingua que naquela sociedade era símbolo do status elevado, acontecía tamén, por outra, que a situación de suma precariedade en que o ensino primario permaneceu ata o século XX tampouco abría oportunidades para que por esta vía puidesen acceder ó coñecemento e uso do castelán numerosos galegos. Nestas circunstancias, só factores como a prédica relixiosa ou a mobilidade xeográfica resultante da emigración (ata a segunda metade do século XVIII, preferentemente temporeira no Reino de Galicia) podían actuar como axentes introductores do castelán para a inmensa maioría dos galegos daquel tempo.

Que o monolingüismo en galego era a norma entre as grandes camadas de agricultores, gandeiros, mariñeiros ou pequenos artesáns e comerciantes da Galicia do Ántigo Réxime é hoxe algo que semella indiscutible e que de feito ninguén cuestiona nas obras que tratan da historia lingüística de Galicia neste período. A elas me remito para non aburri-lo lector con cousas hoxe xa moi coñecidas. A escola primaria, que no século XVIII comeza a ser impulsada polos Borbóns cunha 
orientación linguiisticamente castelanizante, resultaba ser aínda un axente uniformizador moi débil no conxunto do Reino de España. Así se expresaba en 1800 Francisco del Valle-Inclán en El Catón Compostelano:

Por mas esfuerzos que hace el Ministerio con los Vascones, ni nosotros, ni los Arabes, Godos, y Romanos han podido forzarlos á olvidar su Vascuence. Lo mismo sucede á los Gallegos, Catalanes, y Valencianos, se nos estrecha á hablar y escribir en Castellano; y en el acto de arrojar las tablas de la Escuela se vuelven los niños, se explican, divierten, y desahogan en su lengua nativa (El Caton Compostelano, 1800, Discurso II, p. 23).

Ó se inicia-lo século XIX, os diversos factores de todo tipo que se opoñían á penetración do castelán en Galicia eran tan poderosos que Francisco del ValleInclán viña a concibi-lo idioma galego como elemento irremovible da paisaxe humana da nosa terra: "nuestro Gallego es, fué, y será el mismo, sin que haya poder humano capaz de alterarlo" (El Caton Compostelano, 1800, Discurso II, p. 28).

Como grupo intermedio e intermediario entre a alta nobreza laica e eclesiástica e o pobo común, entre rendistas e rendeiros, a fidalguía galega no puido deixar de ir integrando o castelán na súa conducta lingüística. Emporiso, dado que a fidalguía galega do Antigo Réxime non era un grupo social monolítico, senón dotado dunha notable diversidade interna (cf. Barreiro Fernández 1991: 221-240), non lle podemos atribuír un único modelo de comportamento lingüístico. Sen dúbida, estarían máis próximos do monolingüismo en galego os fidalgos de economía máis directamente vinculada ó traballo agropecuario e de formas de vida fundamentalmente rurais, mentres que tenderían ó uso habitual do castelán os fidalgos, a miúdo segundoxénitos, que se integraban na administración civil e eclesiástica e na milicia, e en xeral aqueles imbuídos da necesidade da ostentación, do gasto suntuario, da etiqueta, da vida de señorío. Obviamente, entre os dous extremos posibles cabería unha ampla gama de conductas intermedias.

A iniciativa de funda-la Academia Compostelana en 1731 partiu, como xa se dixo, de oito manteístas, estudiantes ordinarios e amplamente maioritarios na Universidade de Santiago de Compostela que, aínda que non gozaban dos privilexios dos colexiais de Fonseca e San Clemente, eran "en boa parte de orixe fidalga ou naceran no seo de familias dedicadas á administración e ó comercio, con valores sociais e mentais moi próximos ós da fidalguía” (Gasalla Regueiro / Saavedra 1998: 284). Si tiña condición fidalga, con certeza, o compañeiro con quen ó final do Theatro Moral conversa Pablo Mendoza de los Ríos; o autor afirma del que era "tan rancio en lo ydalgo como en lo codio" (Mendoza de los Rios 1731: "Prólogo, o lo que fuere", s.p.). Estou convencido de que durante moito tempo o noso idioma, preterido no exercicio da docencia, na administración e nos actos formais da Universidade de Santiago ou de institución situadas na súa periferia, tivo que permanecer presente na conversa distendida dos ambientes académicos e 
estudiantís da cidade, nos que formaban grupo numeroso os fidalgos de procedencia rural. A conversa galego-castelá, desenvolvida sen que o individuo galegofalante se sentise obrigado a cambiar de código, debeu de ser elemento relativamente común na vida vilega ou cidadá do século XVIII, como creo deixan adiviña-las páxinas finais da obra que estamos a analizar. Como xa expuxen noutra ocasión (Mariño Paz 1999: 230, 239-240), coido que existen diversos indicios que, colocados a carón da análise da sociedade galega da época, fundamentan a miña convicción de que a principios do século XVIII o galego aínda debía de correr como lingua de relación familiar en moitas casas fidalgas, e especialmente nas do mundo rural.

Dito isto, vai de seu que ó meu xuízo non é outra cousa cá esixencia de verismo o que motivou que se redactasen en galego as liñas do libro de Mendoza que son obxecto de estudio deste artigo. Non hai razón ningunha que nos autorice a supoñer motivacións máis complexas, máis vinculadas a algunha sorte de vindicación galeguista, máis ideoloxizadas. En realidade, só con moito e inxustificado voluntarismo poderiamos sinalar, no século XVIII ou nos séculos escuros en xeral, algún manuscrito ou publicación que removese seriamente o esquema sociolingüístico, sociocultural e socioliterario que na Galicia daquel tempo instauraba o latín e o castelán como as linguas normais para a creación literaria e para a creación e divulgación seria do coñecemento, ó paso que acantoaba o galego no reducto da literatura de transmisión oral e só deixaba espacio para o seu cultivo escrito en ocasións excepcionais a miúdo tinxidas de elementos festivos, epigramáticos ou pseudocoloquiais. O que si podía poñer en cuestión tal status quo era a proposta do Padre Sarmiento para que se elaborasen e publicasen unha gramática e un vocabulario galegos, unha gramática e un vocabulario latinogalegos e libros en galego que versasen sobre historia natural, xeografía e onomástica, propostas que, como ben se sabe, realizaba o bieito no marco das súas coñecidas posicións sobre a necesidade de introduci-lo ensino do galego e en galego no sistema de educación primaria da Galicia do seu tempo. Que todo isto non dese pasado do mundo virtual ó mundo real é algo que, á luz dos condicionantes históricos en que esta demanda se facía, non pode certamente sorprender.

O galego, en fin, ocupaba unha posición marxinal no marco do debate lingüístico sostido na España dezaoitesca por reducidos grupos de intelectuais, gobernantes e administradores da cousa pública. Tal debate xiraba basicamente ó redor de dous grandes eixes temáticos, magnificamente estudiados por Fernando Lázaro Carreter en Las ideas lingüísticas en España durante el siglo XVIII. Disputábase, por unha parte, sobre a conveniencia de que o castelán acabase de substituír completamente o latín como lingua para a expresión do saber académico, cousa que formalmente non se conseguiu ata as primeiras décadas do século XIX. E discutíase tamén, desde 
actitudes puristas e nacionalistas, sobre a necesidade de opoñer ante o francés, lingua hexemónica da época, algunhas barreiras que impedisen a minusvaloración do castelán e a penetración incontrolada de galicismos no seu sistema. É desde a perspectiva deste segundo debate desde onde mellor se comprende, dunha banda, un dos defectos que o anónimo autor da carta a Mendoza lle vía á Academia Compostelana (que nela "no se enseña Frances") e, da outra, o consello con que a este comentario lle retrucou o compañeiro galegofalante: "y en canto à essa Encademia, ou como se chama, digalle (pois està mais aquestado en essas cousas,) que primeyro è saber falar Español, que deprendelle Frances". Para este personaxe, como para a gran maioría dos que no século XVIII tiñan capacidade para formar opinión no Reino de Galicia e no Reino de España, o galego non entraba para nada en consideración no contexto do debate sobre a pugna entre o castelán e o francés. Só individuos excepcionais coma o Padre Sarmiento mantiveron opinións discrepantes das que entón eran comunmente aceptadas.

Por todo o dito, podemos estar certos de que, fóra do probable uso que del se fixese no trato distendido entre académicos, o idioma galego non se utilizou formalmente nas sesións da Academia Compostelana constituída en 1731 na Rúa da Moeda Vella de Santiago de Compostela.

\section{Bibliografía}

ALGa 2: Instituto da Lingua Galega (1995): Atlas lingüístico galego. Vol. 2: Morfoloxía non verbal. 2 vols. A Coruña: Fundación Pedro Barrié de la Maza, Conde de Fenosa.

Ali, M. Said (1966): Gramática histórica da língua portuguesa. $6^{\mathrm{a}}$ ed. São Paulo: Melhoramentos.

Alonso Hernández, J. L. (1977): Léxico del marginalismo del Siglo de Oro. Universidad de Salamanca.

Álvarez, R. / X. L. Regueira / H. Monteagudo (1986): Gramática galega. Vigo: Galaxia.

Barreiro Fernández, X. R. (1991): A sociedade galega contemporánea. Tradición e modernidade, in F. Rodríguez Iglesias (ed.): Galicia. Historia. A Coruña: Hércules de Ediciones, vol. 5.

Caton Compostelano, El. Santiago: En la Imprenta de la Heredera de Frayz, 1800. Consultáronse os dezaseis números que se conservan na Biblioteca Nacional de Madrid (sign. 1-3980).

CBN: Cancioneiro da Biblioteca Nacional (Colocci-Brancuti). Fac-símile e transcrição. Leitura, comentários e glossário por Elza Paxeco Machado e José Pedro Machado. 8 vols. Lisboa: Revista de Portugal, 1949-1964. 
Contenda: R. Mariño Paz (1997b): "Edición do Entremés famoso sobre a pesca do río Miño (1671)", Ensaio. Revista de Teatro de Galicia e do Norte de Portugal 1, s.p.

Cor-Pasc.: Corominas, J. / J. A. Pascual (1987/1989/1991): Diccionario crítico etimológico castellano e hispano. 6 vols. Madrid: Gredos a vol. 1: 1987; vols. 2, 3, 4: 1989; vols. 5, 6: $1991^{\circ}$.

Couceiro Freijomil, A. (1951-1954): Diccionario bio-bibliográfico de escritores. 3 vols. [vol. 1, 1951; vol. 2, 1952; vol. 3, 1954]. Santiago de Compostela: Bibliófilos Gallegos.

Cunha, A. Geraldo da (1994): Dicionário Etimológico Nova Fronteira da Língua Portuguesa. $2^{\text {a }}$ ed. revista e acrescida de um suplemento. Rio de Janeiro: Nova Fronteira; $1^{\mathrm{a}}$ ed.: 1982.

Franco Grande, X. L. (1968): Diccionario galego-castelán e vocabulario castelángalego. Vigo: Galaxia. Utilicei a $4^{\text {a }}$ edición (1978).

Freixeiro Mato, X. R. (2000): Gramática da lingua galega. II. Morfosintaxe. Vigo: A Nosa Terra.

García, C. (1985): Glosario de voces galegas de hoxe. Anexo 27 de Verba. Santiago de Compostela: Universidade.

García, C. / M. González González (dirs.) (1997): Diccionario da Real Academia Galega. A Coruña / Vigo: Real Academia Galega / Xerais / Galaxia.

Gasalla Regueiro, P. L. / P. Saavedra (1998): “A Universidade na primeira metade do século XVIII. Os grupos de poder”, in X. R. Barreiro (coord.): Historia da Universidade de Santiago de Compostela. Vol. I. Das orixes ó século XIX. Universidade de Santiago de Compostela, pp. 251-293.

GE: R. Martínez López (1963): General Estoria. Versión gallega del siglo XIV (Ms. O. I. I. del Escorial). Edición, introducción lingüística, notas y vocabulario de Ramón Martínez-López. Universidad de Oviedo. Tivéronse en conta as correccións de R. Lorenzo / X. L. Couceiro (1999): "Correccións á edición da General Estoria de Ramón Martínez López (I)”, in R. Álvarez / D. Vilavedra (eds.): Cinguidos por unha arela común. Homenaxe ó profesor Xesús Alonso Montero. Universidade de Santiago de Compostela, vol. 1, pp. 595-627; e R. Lorenzo / X. L. Couceiro (1999): “Correccións á edición da General Estoria de Ramón Martínez López (II)", in T. García-Sabell Tormo et al. (eds.): Homenaxe ó profesor Camilo Flores. Universidade de Santiago de Compostela, vol. 2, pp. 209-233.

Iglesia, A. de la (1886): El idioma gallego. Su antigüedad y vida. 3 vols. A Coruña: La Voz de Galicia. Reed.: A Coruña: La Voz de Galicia, 1977.

Instituto da Lingua Galega / Real Academia Galega (1995): Normas ortográficas $e$ morfolóxicas do idioma galego. $12^{\mathrm{a}}$ ed. revisada. Vigo: ILG / RAG; $1^{\mathrm{a}}$ ed.: 1982. 
Lapa, M. Rodrigues (1970): Cantigas d'escarnho e de mal dizer dos cancioneiros medievais galego-portugueses. $2^{\mathrm{a}}$ ed. revista e acrescentada. Vigo: Galaxia.

Lázaro Carreter, F. (1985): Las ideas lingüísticas en España durante el siglo XVIII. Madrid: Crítica.

LCP: A. Rodríguez González (ed.) (1989): Livro do Concello de Pontevedra (14311463). Pontevedra: Museo de Pontevedra.

Lloyd, P. M. (1993): Del latín al español. I. Fonología y morfología históricas de la lengua española. Madrid: Gredos. Ed. orixinal: From Latin to Spanish. Vol. I: Historical phonology and morphology of the Spanish language. Philadelphia: American Philosophical Society, 1987.

López, P. A. (1953): La imprenta en Galicia. Siglos XV-XVIII. Madrid: Biblioteca Nacional. Ed. facsímil: Santiago de Compostela: Xunta de Galicia, 1987.

Maia, C. de Azevedo (1986): História do galego-português. Estado linguístico da Galiza e do Noroeste de Portugal do século XIII ao século XVI (com referência à situação do galego moderno). Coimbra: Instituto Nacional de Investigação Científica.

Maia, C. de Azevedo (1988): “Antecedentes medievais do 'seseo' galego”, in Homenaje a Alonso Zamora Vicente. Madrid: Castalia, pp. 33-44.

Mariño Paz, R. (1991): Estudio fonético, ortográfico e morfolóxico de textos do Prerrexurdimento galego (1805-1837). Microficha. Santiago de Compostela: Universidade.

Mariño Paz, R. (1995): "Estudio introductorio", in Fr. M. Sarmiento: Coloquio de vintecatro galegos rústicos. Edición de Ramón Mariño Paz. [Santiago de Compostela]: Consello da Cultura Galega, pp. 7-102.

Mariño Paz, R. (1997a): “Sobre a elaboración do galego escrito polo Padre Sarmiento", in Actas do Congreso Internacional do Tricentenario de Fr. Martín Sarmiento (1695-1995): O Padre Sarmiento e o seu tempo (Santiago de Compostela, 29 de maio - 3 de xuño de 1995). Santiago de Compostela: Consello do Cultura Galega / Universidade de Santiago de Compostela, vol. 2, pp. 89-119.

Mariño Paz, R. (1997b): "Sobre o uso dos grafemas $<b>$, $<$ u $>$ e $<v>$ en textos do galego medio", Cadernos de Lingua 15, pp. 5-70.

Mariño Paz (1999): Historia da lingua galega. $2^{\mathrm{a}}$ ed. Santiago de Compostela: Sotelo Blanco.

Mendoza de los Rios, P. (1731): Theatro Moral, y Político de la Noble Academia Compostelana. Con la adicion curiosa de diversos assumptos, conforme a lo que en ella se practica. Por sv Fundador, y Presidente Don Pablo Mendoza de los Rios. Quien le consagra al idolo de las Veneraciones, el Señor Marqués de Vianze, señor de Rionegro. Santiago: [s.n.]. [Biblioteca Xeral da Universidade de Santiago de Compostela (Res. Ga. 22)]. 
Mendoza de los Rios, P. (1737): Epítome de la portentosa vida y milagros de la gran virgen y protomártir Santa Tecla y descripción de las magníficas suntuosas fiestas a la colocación de esta imagen en su nueva maravillosa capilla inclusa en la Santa Metropolitana Iglesia de Burgos, construida a expensas del Ilmo. Sr. D. Manuel de Samaniego y Jaca, su dignísimo arzobispo, del Consejo de S. $M$. Burgos: Herederos de Juan de Villar. [Biblioteca Xeral da Universidade de Santiago de Compostela ( $\mathrm{R}$ - 18.851].

MS: J. L. Pensado (1958): Miragres de Santiago. Edición y estudio. Anejo 58 da Revista de Filología Española. Madrid.

Neira de Mosquera, A. (1850): "La Academia Compostelana (1731)", in Monografías de Santiago. Santiago de Compostela: Imp. de la Viuda de Compañel e Hijos, pp. 177-194. Reed. con adicións: Monografías de Santiago y dispersos de temas compostelanos (1844-1852). Estudio preliminar de Benito Varela Jácome. Santiago de Compostela: Bibliófilos Gallegos, 1950.

Penny, R. (1991): A History of the Spanish Language. Cambridge: Cambridge University Press.

Pensado, J. L. (1985): “Marginalismos en gallego", in El gallego, Galicia y los gallegos a través de los tiempos. A Coruña: La Voz de Galicia, pp. 95-97.

Real Academia Española (1726-1739): Diccionario de la lengua castellana, 6 vols: vol. 1: Madrid: Francisco del Hierro, 1726; vol. 2: Madrid: Francisco del Hierro, 1729; vol. 3: Madrid: Viuda de Francisco del Hierro, 1732; vol. 4: Madrid: Herederos de Francisco del Hierro, 1734; vol. 5: Madrid: Herederos de Francisco del Hierro, 1737; vol. 6: Madrid: Herederos de Francisco del Hierro, 1739. Ed. facsímil: Diccionario de Autoridades. 3 vols. Madrid: Gredos, 1990.

Real Academia Española (1850): Prontuario de ortografia de la lengua castellana, dispuesto de Real Órden para el uso de las escuelas públicas. Con arreglo al sistema adoptado en la novena edicion de su diccionario. $3^{\mathrm{a}}$ ed. Madrid: Imprenta Nacional.

Real Academia Gallega (1913-1928): Diccionario gallego-castellano (A-CATIVO). A Coruña: RAG.

Relazón: "Relazon da carta xecutovria", in F. de Saavedra Rivadeneyra y Aguiar Pardo de Figueroa (1674): Memorial/ al Rey N. Señor,/ en que se recopila, adiciona y representa/ quanto los Cronistas, y otros autores han escrito, y consta por instrumentos,/ del origen, y antigüedad, descendencia, y sucesión, lustre/ y servicios/ de la casa de Saavedra,/ y de identidad, y permanencia de su primitivo/ Solar, y estados en el reyno de Galicia,/ y de la linea primogénita, recta y troncal de varon/ de sus Posseedores, Cabeças, y Parientes mayores, continuada desde los/ primeros siglos de su mas antigua fundación, hasta/ el presente. / Por don --,/ sucesor, y actual posseedor della, Año de 1674. Con 
licencia: En Granada, en la Imprenta Real de Francisco de Ochoa, en la Calle de Abenamar, pp. 137-138.

Rodríguez González, E. (1958-1961): Diccionario enciclopédico gallego-castellano. 3 vols. Vigo: Galaxia: 1958 (I) / 1960 (II) / 1961 (III).

Sarmiento, Fr. M. (1973): Catálogo de voces y frases de la lengua gallega. Edición y estudio por J. L. Pensado. Universidad de Salamanca.

Sarmiento, Fr. M, (1995): Coloquio de vintecatro galegos rústicos. Edición de Ramón Mariño Paz. [Santiago de Compostela]: Consello da Cultura Galega.

Silva Domínguez, C. (1993): “A combinatoria do posesivo na frase nominal”, Cadernos de Lingua 8, pp. 135-155.

Sobreira, Fr. J. (1979): Papeletas de un diccionario gallego. Ms. s. XVIII. Edición y estudio crítico por J. L. Pensado. Ourense: Instituto de Estudios Orensanos "Padre Feijóo".

TC: Lorenzo, R. (1975-1977): La traducción gallega de la Crónica General y de la Crónica de Castilla. 2 vols. [Vol. 1: Introducción, texto anotado e índice onomástico, 1975. Vol. 2: Glosario, 1977]. Ourense: Instituto de Estudios Orensanos "Padre Feijoo".

USC: M. X. Justo Martín / M. Lucas Álvarez (1991): Fontes documentais da Universidade de Santiago de Compostela. Pergameos da serie Bens do Arquivo Histórico Universitario (Anos 1237 / 1537). Edición diplomática. Santiago de Compostela: Consello da Cultura Galega.

Varela Barreiro, X. (1997): “A existencia de dúas expresións clíticas de segunda persoa singular en galego", in B. Fernández Salgado (ed.): Proceedings of the 4th International Conference on Galician Studies (University of Oxford, 26-28 September 1994) / Actas do IV Congreso International de Estudios Galegos (Universidade de Oxford, 26-28 setembro 1994). Oxford: Center for Galician Studies / Centro de Estudios Galegos, vol. 1, pp. 319-342. 